\title{
A Systematic Literature Review: The Relationship between Indonesian Culture and Other Aspects
}

\author{
Husni Mubarok ${ }^{1}$, Nurul Fadilah ${ }^{2}$, and Moh Toyyib ${ }^{3}$ \\ ${ }^{1}$ Graduate Institute of Digital Learning and Education, National Taiwan University of \\ Science and Technology, Taiwan \\ ${ }^{2}$ Study Program of Natural Science Education, University of Trunojoyo Madura, \\ Indonesia \\ ${ }^{3}$ Accunting Department, University of Trunojoyo Madura, Indonesia
}

\begin{abstract}
This article aimed to present the relationship between Indonesian culture with various aspects (education, welfare, arts, and religion) and showing the uniqueness of Indonesian culture. The procedural of this systematic review used the Suprapto et al. (2020) guided method, including defining the purpose, conducting literature, selecting articles, reading the full paper, abstracting data, and performing analysis. The articles' criteria to be analyzed must be in the English version, published in the social sciences citation indexed (SSCI) journal in the period of 2016-2020. The articles included four fields (education, welfare, art, and religion) as a representation of Indonesian intercultural in several aspects. The result of this study showed that there was an interplay between Indonesian culture and four aspects of the fields, even between aspects. Although Indonesia has a lot of cultures and several aspects would be influenced. However, religion is the strongest aspect related to the Indonesian culture.
\end{abstract}

Keywords: Indonesian culture; intercultural; social; religion

\section{INTRODUCTION}

Indonesia is an archipelago that includes more than 17,000 islands inhabited by around 267 million people, with diverse cultures. There are 1,340 ethnicities and 652 regional languages spread across Indonesia. Every culture which is displayed has a certain uniqueness that makes itself different from other cultures. So it is very interesting to learn and discuss, how each culture influences several aspects or even overall aspects of life.

Intercultural development in Indonesia has an important influence in various fields, including education, welfare, arts, and religion fields. Most of the research on intercultural focuses on the education field (Gandana \& Parr, 2013; Perry \& Southwell, 2011; Salgado-Orellana, Luna, \& Sánchez-Núñez, 2019; Tulak, Wijaya, Rante, Nurmadiah, \& Helaluddin, 2019). For example, the study conducted by Dogancay-Aktuna (2005) describes how information about intercultural communication integrated with methodological training can foster greater awareness of sociocultural relativity in participants, and facilitate their reflection on their presuppositions about 
the target group of learners when they create decisions-making. Furthermore, research was also carried out by Abdullah and Lulita (2019) on social actors in an intercultural communication classroom, where intercultural communication teachers were described as actor teachers who try to encourage their students to be tolerant, critical, supportive, and open-minded people. Meanwhile, research conducted by Qoyyimah, Singh, Exley, Doherty, and Agustiawan (2020) reveals that self-professionalism in intercultural studies of international language was more influenced by moral caregivers or guardians than English teachers in schools. This study showed that the role of culture was very influential in the education of students, whether it was in the family environment or at school, especially in boarding school, in which there was a lot of boarding school in Indonesia.

Apart from the educational aspect, there was intercultural research on other aspects too. Such as welfare aspect, carried out by Schokkaert and Devooght (2003), in this study, talked about responsibility-sensitive fair compensation in different cultures. The participants came from three countries (Belgium, Burkina Faso, and Indonesia), the results show that Belgian students prefer redistribution, while Indonesian students were the most conservative. Generally, in Indonesia, intercultural research has a strong influence on religion (Aini, \& Syarifuddin, 2018; Liem, 2019; Qoyyimah et al., 2020), such as research conducted by Hoon (2017), which discusses multiculturalism as conceptualized policies, discourses, and practices, which were applied in Indonesia. From this research shows that the case for "global discourse" multiculturalism to be seriously considered as a policy practice in Indonesia. Religious multiculturalism encourages the idea of an active state that protects religious minorities and incorporates the inclusive national ideology of Pancasila in its framework. Other study talks about the centrality of spirituality or religion in the culture of palliative care service in Indonesia was done by Rochmawati, Wiechula, and Cameron (2018), which showed that an understanding that religious and spiritual practices are integral cultural elements and of fundamental importance to the holistic health of their patients is necessary if health-care professionals are to support patients and their families in end-of-life care.

The significance of cultural influences in various aspects in Indonesia shows the strong identity of the Indonesian nation. This one invites various researchers from within or outside the country, ranging from research on specific cultures in certain regions in Indonesia to intercultural relations with other countries. However, only several systematic literature review article that summarizes the various studies in one container. Therefore, this article aims to present the uniqueness of Indonesian culture, which has a relationship on various aspects (education, welfare, arts, and religion) in a systematic literature review. The research questions of the current study are:

- To what extent is the relationship between Indonesian culture and education?

- To what extent is the relationship between Indonesian culture and welfare?

- To what extent is the relationship between Indonesian culture and art?

- To what extent is the relationship between Indonesian culture and religion? 


\section{METHOD}

\section{The procedure of systematic review}

This study used the article selection method as guided by Suprapto et al. (2020). In selecting articles, certain procedures are required. Generally, overall the articles were used in Indonesian cultural domains in a variety of fields. This procedure follows the instructions in Figure 1. The first process begins with creating and defining the purpose and research object, then continues with searching for words or sentences through literature searches.

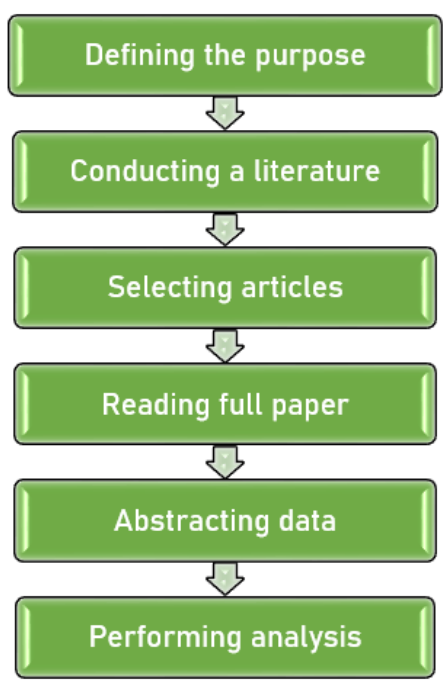

Figure 1. The procedure of systematic literature review

Figure 1 illustrates the schematic procedure of a systematic literature review. The systematic literature review process followed the directions of previous studies conducted by Suprapto and Chang (2015) and Suprapto et al. (2020). The first step was defining the purpose, which means that determining, creating, and defining the topic or idea that will be used to review the research focus. Second, look for literacy or articles according to the topic of the idea to be used. Third, selecting the articles in which appropriate with the topic in Indonesian culture based on the title. When the article was obtained, the fourth was reading the abstract of the article and continuing reading the entire article if the abstract was suitable. By reading the article as a unit, the researcher will be able to read the research data and then analyze it according to the contents of the data.

\section{Selecting studies process}

The researcher used the Web of Science as a search term to find the articles, with four criteria to further analysis. First, the articles must be in the English version, to easily explore the funding and crosscheck the content. Second, the articles should be published in the Social Sciences Citation Indexed (SSCI) journal. As shown in Table 1, the names of journals published in the SSCI journal are Discourse-Studies in the Cultural Politics of Education, Bijdragen Tot De Taal- Land- En Volkenkunde, Journal of the Royal Anthropological Institute, and Asian Journal of Social Psychology. The third was articles published in the period of 2016-2020. The last, articles included in 4 fields (education, welfare, art, and religion) as a representation of Indonesian intercultural in 
several aspects. Because of this study is limited data, the researcher selected four articles as representative of each field. Naidu (2020), with the title "Attending to 'culture' in intercultural language learning: A study of Indonesian language teachers in Australia" as education field, Maulana, Khawaja, and Obst (2019) entitle "Development and validation of the Indonesian Wellbeing Scale" as welfare field, Jurriens (2019) with the title "The countryside in Indonesian contemporary art and media" as art field, and Hefner (2019) entitle "On fun and freedom: young women's moral learning in Indonesian Islamic boarding schools" as religion field.

Table 1. Selected articles data

\begin{tabular}{|c|c|c|c|}
\hline Reference & Title & Journal & Field \\
\hline Naidu, K. (2020) & $\begin{array}{l}\text { Attending to 'culture' in intercultural } \\
\text { language learning: A study of Indonesian } \\
\text { language teachers in Australia }\end{array}$ & $\begin{array}{l}\text { Discourse-Studies in the } \\
\text { Cultural Politics of } \\
\text { Education }\end{array}$ & Education \\
\hline $\begin{array}{l}\text { Maulana, H., } \\
\text { Khawaja, N., \& Obst, } \\
\text { P. (2019) }\end{array}$ & $\begin{array}{l}\text { Development and validation of the } \\
\text { Indonesian Well-being Scale }\end{array}$ & $\begin{array}{l}\text { Asian Journal of Social } \\
\text { Psychology }\end{array}$ & Welfare \\
\hline Jurriens, E (2019) & $\begin{array}{l}\text { The countryside in Indonesian } \\
\text { contemporary art and media }\end{array}$ & $\begin{array}{l}\text { Bijdragen Tot De Taal- } \\
\text { Land-En Volkenkunde }\end{array}$ & Art \\
\hline Hefner, C. M. (2019) & $\begin{array}{l}\text { On fun and freedom: young women's moral } \\
\text { learning in Indonesian Islamic boarding } \\
\text { schools }\end{array}$ & $\begin{array}{l}\text { Journal of the Royal } \\
\text { Anthropological Institute }\end{array}$ & Religion \\
\hline
\end{tabular}

\section{RESULT AND DISCUSSION}

From the four articles selected have various research areas, as represent the four field focus. Most participants of this review from Java island, where Java island as a political canter in Indonesia. Like the research have done by Hefner (2019), the participants of her study are Middleschool (Madrasah Tsanawiyah) and High-school (Madrasah Aliyah) Muslim girl students in Madrasah Mu'allimaat Muhammadiyah and Pesantren Krapyak Ali Maksum in Yogyakarta city, south-central Java, Indonesia. Moreover, Jurriens (2019) also used the Java area as his research participant. The focus participants on Bandung-based Common Room Networks Foundation and the Kasepuhan Ciptagelar community in rural West Java, Indonesia. On the other hand, the research of Maulana et al. (2019) utilizes the Indonesian adults as their research participant, were 1,028 (68\% females, 32\% males) adults recruited from 24 provinces, with various ethnic populations. The purpose of this research to describes the development and validation of new instruments for measuring the well-being of Indonesians and also for understanding experiences and factors related to well-being in a particular cultural context.

As shown in Table 2, half of the four studies did not clearly define the research period. Actually, in Jurriens's (2019) study also did not clearly explain the total duration of his research, he just mentions a twenty-day project for mapping areas. Only in the Hefner (2019) study which clearly explains the total period of her study, twenty-one months in the two Islamic schools. 
The majority of the research method of this review was a qualitative method. A quarter of this review used the quantitative method, was Maulana et al. (2019) study. For collecting data of this research used online and paper-based survey to build the new instrument for the Indonesian Well-being Scale (IWS). For qualitative method used semi-structured in-depth interviews and documentation. As done by Hefner (2019), she conducted semi-structured in-depth interviews with teachers, students, administrators, alumni, parents, and local activists. And they also distributed a survey to over three hundred students with questions about their family socioeconomic background, schooling experiences, hopes for futures careers, views on dating, and leisure activities.

Furthermore, the study conducted by Naidu (2020), interviewed ten teachers currently teaching Indonesian in New South Wales schools. The interest of this research was a desire to further explore the ways in which 'culture' and 'intercultural understanding' are being conceptualized in the field. The last was carried out by Jurriens (2019) using interviews and a combination of modern technology for documentation, such as Global Positioning System (GPS) tagging and drone-mounted cameras for taking traditional activities and mapping the traditional territorial border-marking by the Ciptagelar community.

Table 2. An overview of the research methodology of this review

\begin{tabular}{|c|c|c|c|}
\hline Reference & Participant and location & Period of study & Research method \\
\hline Naidu, K. (2020) & $\begin{array}{l}10 \text { teachers currently teaching Indonesian in New } \\
\text { South Wales schools (in primary, secondary, or } \\
\text { both). }\end{array}$ & $\begin{array}{l}\text { One period, } \\
\text { undefined } \\
\text { clearly }\end{array}$ & $\begin{array}{l}\text { Qualitative } \\
\text { method }\end{array}$ \\
\hline $\begin{array}{l}\text { Maulana, H., } \\
\text { Khawaja, N., \& } \\
\text { Obst, P. (2019) }\end{array}$ & $\begin{array}{l}\text { Participants were } 1,028 \text { ( } 68 \% \text { females, } 32 \% \text { males) } \\
\text { Indonesian adults, recruited from } 24 \text { provinces, } \\
\text { with various ethnic populations in Indonesia }\end{array}$ & $\begin{array}{l}\text { One period, } \\
\text { undefined } \\
\text { clearly }\end{array}$ & $\begin{array}{l}\text { Quantitative } \\
\text { method }\end{array}$ \\
\hline Jurriens, E (2019) & $\begin{array}{l}\text { Bandung-based Common Room Networks } \\
\text { Foundation and the Kasepuhan Ciptagelar } \\
\text { community in rural West Java, Indonesia. }\end{array}$ & $\begin{array}{l}\text { Twenty-day } \\
\text { project for } \\
\text { mapping area }\end{array}$ & $\begin{array}{l}\text { Qualitative } \\
\text { method }\end{array}$ \\
\hline $\begin{array}{l}\text { Hefner, C. M. } \\
\text { (2019) }\end{array}$ & $\begin{array}{l}\text { Middle-school (Madrasah Tsanawiyah) and High- } \\
\text { school (Madrasah Aliyah) Muslim girl students in } \\
\text { Madrasah Mu'allimaat Muhammadiyah and } \\
\text { Pesantren Krapyak Ali Maksum in Yogyakarta } \\
\text { city, south-central Java, Indonesia }\end{array}$ & $\begin{array}{c}\text { Twenty-one } \\
\text { months }\end{array}$ & $\begin{array}{l}\text { Qualitative } \\
\text { method }\end{array}$ \\
\hline
\end{tabular}

\section{Indonesian culture in education}

According to Naidu (2020) study, which attending the culture in intercultural language learning reveal that culture was too hard to define in simple word. It was appropriate with the explanation of the participants in her study,

...Indonesian culture, it's a bit hard to define, because it's made up of many...cultures.

So it's a bit hard to say to students...this is what Indonesian culture looks like, as opposed to...like Japanese culture is very mono-cultural... 
And other participant said that:

...otherwise they just think, 'Oh, you're an Indonesian', like you're an Australian, you know. But it's not like that, and it's hard for them to get the concept that Indonesia's actually a very multicultural country... and I don't think all countries are necessarily as diverse as Indonesia.

This quote shows an understanding of 'diversity' as a major function of 'ethnicity'. They have compared the cultural conditions of Indonesia with other countries that were more simple. They consider that this diversity was viewed as both a challenge and a teaching opportunity.

Based on the Australian curriculum, assessment, and reporting authority (2015) that talk about culture and intercultural argue that the term 'intercultural understanding' was one of among many terms used to describe a set of attributes which enable a person to interact effectively with people from diverse cultures. In education filed, this one was paraller with Dervin and Liddicoat (2013) state, 'that there are different ways of approaching intercultural education, which depend on how the intercultural is understood' and these differences constitute a kind of "conceptual jungle" for teacher, practitioners, and scholars.

The essentialist notion of culture, linked to a reductive understanding of race, ethnicity, or nationality, is no longer sufficient, but opposing views of a completely fluid approach also presents problems, especially in Indonesia where there are a wide variety of ethnicities, races, and ethnicities. Therefore, analyzing understandings of 'culture' is essential if teachers are to avoid falling back into essential and coherent understandings of culture that could influence their pedagogical approach. It was in one line with Kohler (2015) notes:

The teachers construct relationships between students and the new language and culture, positioning them as observers, analysts, interpreters and participants of how learners can relate to 'otherness' and in the process become intercultural mediators.

Kohler highlighted not only the challenging nature of the teacher's role, but also the broader implications of that role, the position of teacher as the intercultural mediator in terms of 'differences'.

\section{Indonesian culture in art}

The main case of Jurriens (2019) study was collaborations between the Bandung-based Common Room Networks Foundation and the Kasepuhan Ciptagelar community in rural West Java to analyses the audio-visual creativity, art scene media in West Java since 1997, and other visual artists. The contemporary art recognizes the 'power of the present' and does not see it merely as a 'transition from the past to the future'. The contemporary here implies 'presence, in the present, beings that were present to one another, at times that happened to exist' (Smith, 2013). On the other hand, contemporary art establishes and thematizes connections with people, objects, and environments in the here and now. In contemporary Indonesian art, the new media arts collective has expressed a desire to coexist by bringing various agents, materials and spaces, including those 
previously neglected, into creative and critical dialogue with one another. Their main focus was to explore the socio-cultural, political, and material dimensions of urban life in Indonesia.

Furthermore, Kasepuhan Ciptagelar is a unique village. This area refers to the modern name of a traditional community in the Mount Halimun, Salak National Park Area, West Java. 'Sepuh' means 'old' in Sundanese, and 'Kasepuhan' refers to a group of elders or a community connected through ancestral customs. The earliest historical records of this community date back to 1368 (Suganda, 2019). And the name of 'Ciptagelar' was adopted in 2001, it was a contraction of the Sundanese verbs nyiptakeun (to create) and ngagelarkeun (to show). It refers to a certain historical phase in which the main village was created in the open area, and the community was willing to present itself to the outside world (Nuryanto, 2008). This is the important part of Indonesian Art of the community inside the culture. Besides the strength of culture, the religion also has the main role of the tradition. It was supported by explanation of Ciptagelar community member, who is also a West Java representative in the Aliansi Masyarakat Adat Nusantara (AMAN, Alliance of Adat Societies of the Archipelago):

The Ciptagelar Kasepuhan indigenous community believes that humans are only one of many living creatures in the universe. In their value system, human beings should respect 'Mother Earth' and 'Father Heaven' just as they respect their own parents. Perceptions of nature must always be related to people's perceptions of themselves as human beings. The underlying concept is Jagat Leutik, Jagat Gede-Jagat Leutik Sanubari, Jagat Gede Bumi Langit: awareness of the microcosm and macrocosm-the small world of consciousness and the immensity of the natural universe.

Art is central to 'thinking and feeling through the Anthropocene', because aesthetics is a tool to counteract 'anesthesia' or human sensory adaptation to human impacts on the natural environment (Davis \& Turpin, 2015). One form of art which expresses a desire to live together is a landscape video accompanied by the music of the Bandung-based experimental group Sound of Hanamangke. The sounds and images reflect the reality of Kasepuhan Ciptagelar as a synthesis of tradition and modernity. The music and imagery promote awareness of the past as an invaluable source of present and future, the two terms of artistic preservation-innovation and sustainability of the social environment.

\section{Indonesian culture in welfare}

Based on the study of Maulana et al. (2019), Indonesia country has a unique condition. Culture and religion have important role in welfare measurement, both of them have been shown in numerous studies to be an important aspect of Indonesian society (Lun \& Bond, 2013; Rahayu, 2016; Hefner, 2019). therefore, it requires a special instrument to measure the level of welfare of the Indonesian people. Maulana et al. (2019) was carried out research twice to enhance our understanding of the well-being of the Indonesian population in a culturally appropriate and comprehensive manner. The first study was done by the qualitative method. The result of this study showed that the importance of a positive worldview, the essence of which was very specific and 
unique to the Indonesian culture. One of the key aspects of this positive worldview is their unconditional acceptance of life, with the concept of Nerimo (Javanese) or Ikhlas (Arabic).

The second study was carried out by quantitative method. The participants were 1,028 Indonesian adults, recruited from 24 provinces with various ethnic populations. The measurement of this study consisted of an information sheet, a consent form, demographic questions, the Indonesian Well-being Scale (IWS), and translated versions of the Satisfaction with Life Scale (SWLS; Diener, Emmons, Larsen, \& Griffin, 1985), and the Warwick-Edinburg Mental Wellbeing Scale (WEMWBS; Tennant et al., 2007). The development of the IWS instrument was the main point of this research, because this instrument was specifically for the Indonesian people or nation that has cultural strength.

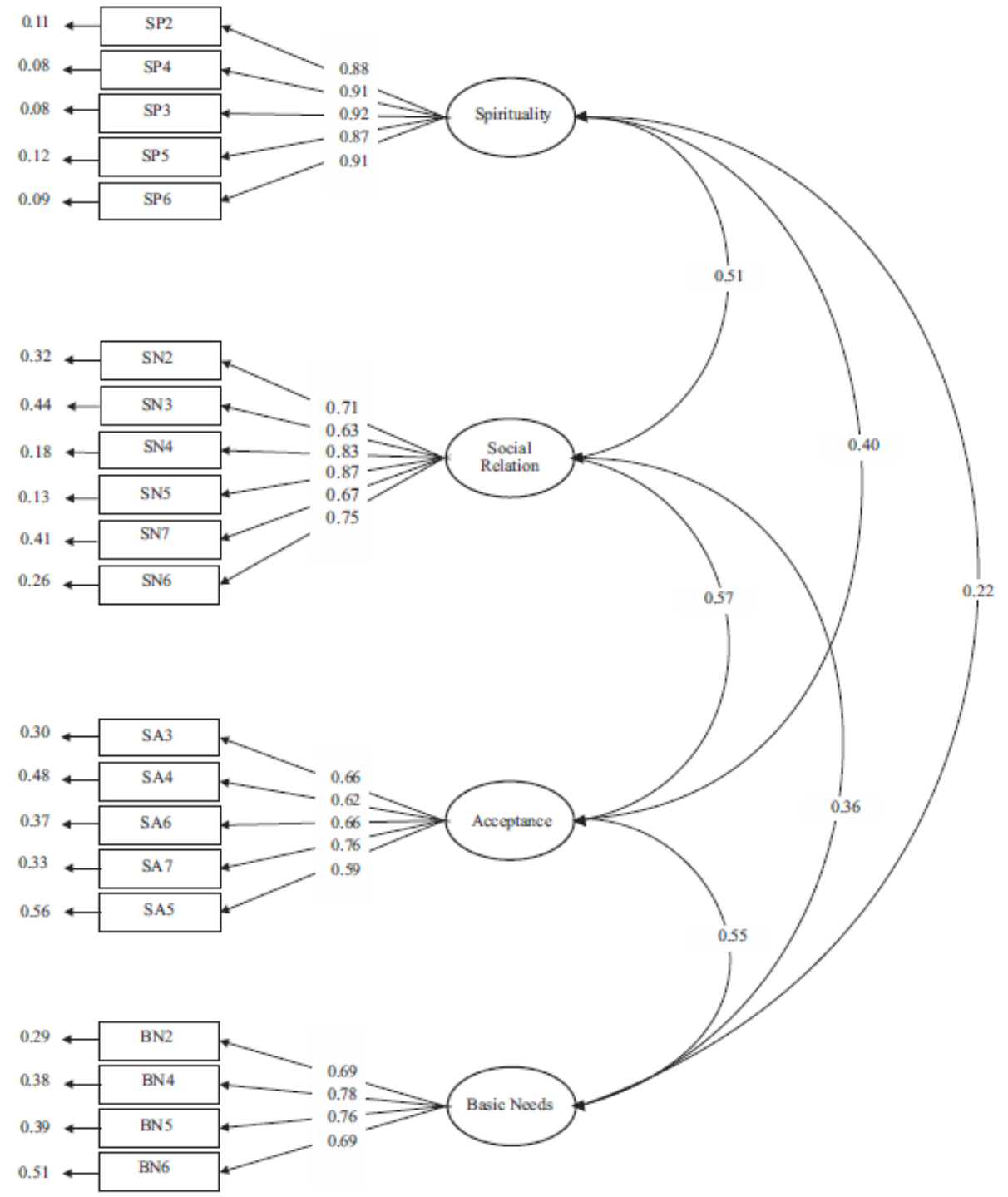

Figure 2. The CFA of the 20-item Indonesian well-being scale (Maulana et al., 2019) 
The final items of IWS instrument were 20 items scale, which measure respondents' perceptions of well-being through four different domains (Spirituality, Positive Social Relations, Basic Needs, and Acceptance). This dimension was in line with emerging literature on well-being in a cross-cultural context. As shown in Figure 2. This study was conducted to develop a culturally appropriate measure of welfare for use with the Indonesian population. The current findings are promising and suggest that the IWS is a powerful psychometric instrument with great potential for building welfare research in the Indonesian context.

\section{Indonesian culture in religion}

The main case of Hefner (2019) research, based on the ethnographic study of two Islamic boarding schools for middle-school (Madrasah Tsanawiyah) and high-school (Madrasah Aliyah) located in the bustling city of Yogyakarta, Indonesia. Both of schools, Madrasah Mu'allimaat Muhammadiyah and Pesantren Krapyak Ali Maksum, come from different Islamic legal, pedagogical, and epistemological backgrounds, the former 'modernist' and the latter 'traditionalist'. This research used a qualitative method with semi-structured in-depth interviews in Indonesian with students, alumni, teachers, administrators, parents, and local activists. To analyses the role of fun and freedom in the moral learning of young women students in Indonesian Islamic boarding schools.

Young female students in Krapyak and Mu'allimaat are upheld by moral standards and social behaviour, dress, appearance, scholarship, and piety. These standards are highly gendered for embodying Indonesian and Islamic understandings of femininity, modesty, and shame (Collins \& Bahar, 2000; Mahmood, 2005). Discipline is an important indication of the quality of schools in Indonesia, with top-ranking (favourite) schools being selected, among other things, because of their strong discipline and non-stop schedules. Discipline is assessed by several measures, including the number of school rules, the busyness of daily routines, and detailed dress codes (Parker \& Nilan 2013). Discipline in religious practice, good behaviour, leadership skills, and good grades are the aim of Islamic educational system. By the slogan 'I must be smart! I must be able to!' ('Saya harus cerdas! Saya harus bisa!') make Islamic student have strong motivation to achieve it. In the other hand, their need to make fun in their life and activities. Several activities for their entertainment are Shalawatan (recitation of Arabic poems), sport, art, etc.

In Indonesia, religion has a very important role in culture, education, way of life, and social control. In the Islamic education, between friends and the environment becomes social control in carrying out worship and social life. Especially in Islamic boarding school life, they were trained

to care for the social environment, to be mentally strong, and self-regulating. Although the environmental conditions are free and could make them affected by negative things, however, by a good education will create students have a good character and attitude. As described by Hilmy Muhammad as Krapyak's director:

We don't have a gate here at Krapyak... Young people who study here have to have a steel mentality (mental yang baja). Kids come here and they see [neighbours, non- 
Islamic boarding-school students] are up to all kinds of bad things. If a student's mentality is not like steel, they will have problems. They may get up to no good and get themselves expelled. But those who are able to stay at Krapyak, they grow accustomed to this ... Their gate must be in their heart. Students from a pesantren that is very closed off, when they leave they will be like horses let loose from a pen; they will run around without a path. But it is different at Krapyak. When students graduate, they aren't surprised to meet [non-pesantren] people (masyarakat); they are able to have normal interactions.

Analyzing moments of fun in the context of Islamic ethical subject formation gives us a clearer sense of the 'multidimensional' nature of moral selfhood (Simon, 2014), that dedication to religious rigour and self-discipline intersects with and informs career, familial, sartorial, social, education, and other aspirations. In particular, Krapyak's emphasis on freedom (freedom) clearly illustrates these Muslim educators' understanding that their young people need guidance and practice in navigating a society driven by various gender and cultural messages and alternative opportunities.

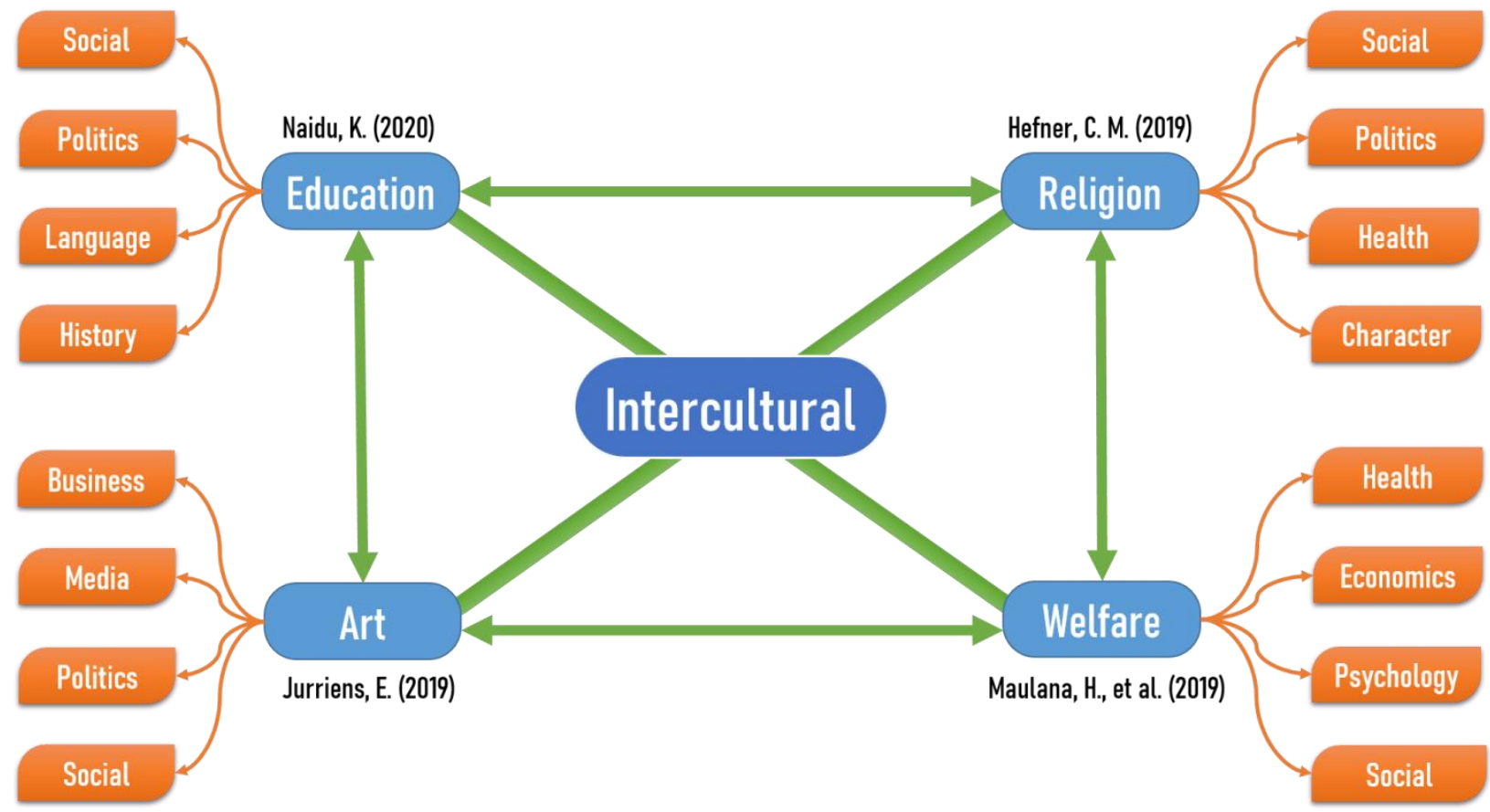

Figure 3. The relationship between Indonesian culture and other aspects

\section{CONCLUSION}

This study investigates the relationship between Indonesian culture and various aspects through a systematic literature review. Based on the four articles that representation in education, welfare, art, and religion fields, there are three points that can be concluded. First, there is an interplay between Indonesian culture and four aspects of the fields, even between aspects, as shown at Figure 3. Second, not only four aspects that have a relationship with culture, but also other 
aspects, such as economics, health, politics, etc. Third, the aspect that has the strongest relationship with Indonesian culture is religion. It means that the Indonesian nation is a religious society and has a strong inner bond with the creator (God).

The limitation of this article is the limited research or articles that analyzed and the research period around 2016-2020. Therefore, it is expected for readers and researchers to take more articles to analyzed in a systematic literature review. Moreover, collecting research/articles in a more extended period, such as ten years, fifteen years, and more. For further study is suggested to analyze more in other aspects, such as politics, social, health, history, and others.

\section{REFERENCES}

Abdullah, F. \& Lulita. (2018). Social actors in an intercultural communication classroom: A discursive lens of intercultural education. Indonesian Journal of English Language Teaching, 13(1), 31-51.

Aini, S. N., \& Syarifuddin, A. (2018). Existence of intention and classification of spiritual quality of students at the boarding school Jagad Alimussirry Surabaya. Journal Intellectual Sufism Research (JISR), 1(1), 15-18.

Australian Curriculum, Assessment and Reporting Authority. (2015). General capabilities. Retrieved December 20, 2020, from http://www.australiancurriculum.edu.au/GeneralCapabilities/

Collins, E. F., \& Bahar, E. (2000). To know shame: Malu and its uses in Malay societies. Crossroads: An Interdisciplinary Journal of Southeast Asian Studies, 35-69.

Davis, Heather and Etienne Turpin (2015). 'Art and death: Lives between the fifth assessment and the sixth extinction', in: Heather Davis and Etienne Turpin (eds), art in the anthropocene: Encounters among aesthetics, politics, environments and epistemologies (pp. 3-29). London: Open Humanities Press.

Dervin, F., \& Liddicoat, A. (2013). Introduction: Linguistics for intercultural education. In F. Dervin, \& A. Liddicoat (Eds.), Linguistics for intercultural education (pp. 1-25). Amsterdam: John Benjamins.

Diener, E. D., Emmons, R. A., Larsen, R. J., \& Griffin, S. (1985). The Satisfaction with life scale. Journal of Personality Assessment, 49(1), 71-75. doi:10.1207/s15327752jpa4901_13

Dogancay-Aktuna, S. (2005). Intercultural communication in English language teacher education. ELT Journal, 59(2), 99-107. doi:10.1093/eltj/cci023

Gandana, I., \& Parr, G. (2013). Professional identity, curriculum and teaching intercultural communication: An Indonesian case study. Language, Culture and Curriculum, 26(3), 229-246. doi:10.1080/07908318.2013.833620

Hefner, C. M. (2019). On fun and freedom: Young women's moral learning in Indonesian Islamic boarding schools. Journal of the Royal Anthropological Institute, 25(3), 487-505. doi:10.1111/14679655.13079

Hoon, C.-Y. (2017). Putting religion into multiculturalism: Conceptualising religious multiculturalism in Indonesia. Asian Studies Review, 41(3), 476-493. doi:10.1080/10357823.2017.1334761

Jurriens, E (2019). The countryside in Indonesian contemporary art and media. Bijdragen Tot De TaalLand- En Volkenkunde, 175 (4), 446-473. doi:10.1163/22134379-17502023

Kohler, M. (2015). Teachers as mediators in the foreign language classroom. Retrieved from http://UWSAU.eblib.com.au/patron/FullRecord.aspx?p=1920436 
Liem, A. (2019). Doing my profession is also part of worship: How clinical psychologists address aspects of spirituality and religion in Indonesia. Journal of Religion and Health. doi:10.1007/s10943-01900880-0

Lun, V. M. C., \& Bond, M. H. (2013). Examining the relation of religion and spirituality to subjective wellbeing across national cultures. Psychology of Religion and Spirituality, 5, 304-315. doi:10.1037/a0033641

Mahmood, S. (2005). Politics of piety: The Islamic revival and the feminist subject. Princeton, Oxford: Princeton University Press.

Maulana, H., Khawaja, N., \& Obst, P. (2019). Development and validation of the Indonesian Well-being Scale. Asian Journal of Social Psychology, 22(3), 268-280. doi:10.1111/ajsp.12366

Naidu, K. (2020). Attending to 'culture' in intercultural language learning: A study of Indonesian language teachers in Australia. Discourse-Studies in the Cultural Politics of Education, 41(4), 653-665. doi:10.1080/01596306.2018.1548430

Nuryanto (2008). Ruang publik dan ritual warga kampung Kasepuhan Ciptagelar di Kabupaten Sukabumi. Jurnal Penelitian Pendidikan, 48-59.

Parker, L., \& Nilan, P. (2013). Adolescents in contemporary Indonesia $\left(1^{\text {st }} \mathrm{ed}.\right)$. London: Routledge.

Perry, L. B., \& Southwell, L. (2011). Developing intercultural understanding and skills: Models and approaches. Intercultural Education, 22(6), 453-466. doi:10.1080/14675986.2011.644948

Qoyyimah, U., Singh, P., Exley, B., Doherty, C., \& Agustiawan, Y. (2020). Professional identity and imagined student identity of EIL teachers in Islamic schools. Journal of Language, Identity \& Education, 1-16. doi:10.1080/15348458.2020.1833726

Rahayu, T. P. (2016). The determinants of happiness in Indonesia. Mediterranean Journal of Social Sciences, 7(2), 393-404. doi:10. 5901/mjss.2016.v7n2p393

Rochmawati, E., Wiechula, R., \& Cameron, K. (2018). Centrality of spirituality/religion in the culture of palliative care service in Indonesia: An ethnographic study. Nursing \& Health Sciences, 20(2), 231237. doi:10.1111/nhs. 12407

Salgado-Orellana, N., Berrocal de Luna, E., \& Sánchez-Núñez, C. A. (2019). Intercultural education for sustainability in the educational interventions targeting the Roma student: A systematic review. Sustainability, 11(12), 3238. doi:10.3390/su11123238

Schokkaert, E., \& Devooght, K. (2003). Responsibility-sensitive fair compensation in different cultures. Social Choice and Welfare, 21(2), 207-242. doi:10.1007/s00355-003-0257-3

Simon, G. 2014. Caged in on the outside: Moral subjectivity, selfhood, and Islam in Minangkabau, Indonesia. Honolulu: University of Hawai'i Press.

Smith, T. (2013). Contemporary art: World currents in transition beyond globalization, in: Hans Belting, Andrea Buddensieg and Peter Weibel (eds), The global contemporary and the rise of the new art worlds (pp. 186-92). Cambridge, MA: MIT Press.

Suganda, K. U. (2009). 'The Ciptagelar Kasepuhan indigenous community, West Java: Developing a bargaining position over customary forest', in: Emilianus Ola Kleden, Yuyun Indradi and Liz Chidley (eds), Forests for the future: Indigenous forest management in a changing world (pp. 2763). Jakarta and Hallbankgate: The Indigenous Peoples Alliance and Down to Earth.

Suprapto N. \& Chang, T.-S. (2015). Research on university student's self-efficacy scale in science education: A systematic review. Proceeding of the IConSSE FSM SWCU, 120-129.

Suprapto, N., Sunarti, T., Suliyanah, Wulandari, D., Hidayaatullaah, H. N., Adam, A. S. \& Mubarok, H. (2020). A systematic review of photovoice as participatory action research strategies. International Journal of Evaluation and Research in Education, 9(3), 675-683. doi:10.11591/ijere.v9i3.20581 
Tennant, R., Hiller, L., Fishwick, R., Platt, S., Joseph, S., Weich, S., Stewart-Brown, S. (2007). The Warwick-Edinburgh mental well-being scale (WEMWBS): Development and UK validation. Health and Quality of Life Outcomes, 5(1), 63. doi:10.1186/1477-7525-5-63

Tulak, H., Wijaya, H., Rante, S. V. N., Nurmadiah, \& Helaluddin (2019). The intercultural competence in education era 4.0: A learning strategy for students of elementary school in Indonesia. European Union Digital Library. doi:10.4108/eai.14-9-2019.2289961 